Available online on 15.12.2018 at http://jddtonline.info
Journal of Drug Delivery and Therapeutics
Open Access to Pharmaceutical and Medical Research
$\begin{gathered}\text { 2011-18, publisher and licensee JDDT, This is an Open Access article which permits unrestricted } \\ \text { non-commercial use, provided the original work is properly cited }\end{gathered}$

Open $\odot$ Access

Review Article

\title{
Clinical potency of Patra-Pottali Sweda
}

\author{
Dr. Amit Mukherjee', Dr. O. P. Dwivedi², Dr. Jinesh Jain³ ${ }^{3}$ Dr. Sanjeev Madhukar Rao Khuje ${ }^{4}$ \\ ${ }^{1}$ Associate Professor, Dept. of Panchkarma, Rani Dullaiya Smriti Ayurved P.G. Mahavidyalaya evam Chikitsalaya, Bhopal, India. \\ 2Professor and H.O.D. Sharir Rachana, Govt. (Auto.) Ayurved College \& Hospital, Rewa, India. \\ ${ }^{3}$ Associate Professor, Dept. of Panchkarma, Govt. (Auto.) Ayurved College \& Hospital, Rewa, India. \\ ${ }^{4}$ Associate Professor, Dept. of Rog-Nidana, Govt. (Auto.) Ayurved College \& Hospital, Rewa, India.
}

\section{ABSTRACT}

Swedana Karma is one of the modality of ayurveda acts as Sthambhaghna (removal of stiffness), Gourvaghna (loss of heaviness of the body), Sheetaghana (loss of coldness in the body) and Swedkaraka (producing sweating in the body). Swedana is considered as Bahirparimarjana Chikitsa, one among the Shadupakarmas. It is employed to relieve symptoms like; Shula and Stambha associated with various diseases. Present article emphasized Patra Pottali Sweda (Ela Kizhi) which used to induce perspiration through heated pack of specific herbal leaves in the management of Upastambhita Vyadhi Avastha.

Keywords: Ayurveda, Swedana Karma, Patra Pottali Sweda, Bahirparimarjana Chikitsa.

Article Info: Received 30 Oct 2018; Review Completed 10 Dec 2018; $\quad$ Accepted 12 Dec 2018; Available online 15 Dec 2018

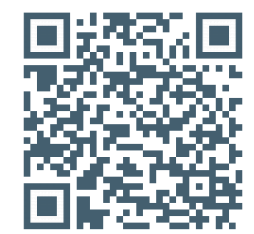

Cite this article as:

Mukherjee A, Dwivedi OP, Jain J, Khuje SMR, Clinical potency of Patra-Pottali Sweda, Journal of Drug Delivery and Therapeutics. 2018; 8(6-s):400-403 DOI: http://dx.doi.org/10.22270/jddt.v8i6-s.2142

\section{*Address for Correspondence:}

Chikitsalaya, Bhopal, India.

Dr. Amit Mukherjee, Associate Professor, Dept. of Panchkarma, Rani Dullaiya Smriti Ayurved P.G. Mahavidyalaya evam

\section{INTRODUCTION}

The procedure which produces Sweating in the body and cures stiffness, heaviness \& coldness of the body is called as "Swedana Karma" or "Sudation" or "Fomentation therapy". Sweda is the Mala (internal excreta) of the body and it is the excreta of the Meda. Sudation therapy is said to be best treatment for Vata and Kapha diseases. After the Snehana or Oleation therapy Swedana or Sudation must be adopted to regulate the movement of urine and feces without any obstruction. ${ }^{1-3}$

\section{REVIEW OF LITERATURE}

\section{Classification of swedana according to Agnibheda:}

Acharya Charaka described two types of Agni Sweda which are Sagni Sweda and Niragni Sweda.

\section{i) Nirangi Sweda:}

There are 10 types has described of Niragni Sweda.

\begin{tabular}{|c|l|l|l|}
\hline 1. & Vyayama (Exercise) & 6. & Bhaya (Fear) \\
\hline 2. & $\begin{array}{l}\text { Ushnasadana (Residing in a warm } \\
\text { chamber) }\end{array}$ & 7. & Upanaha (Application of poultice) \\
\hline 3. & $\begin{array}{l}\text { Gurupravarnam } \\
\text { (Wearing of heavy clothing) }\end{array}$ & 8. & Krodha (Enrangement) \\
\hline 4. & Kshudha (Hunger) & 9. & Aahata (Wresting) \\
\hline 5. & Bahupanam (Excessive drinking) & 10. & Aatapa (Exposure to sun's rays). \\
\hline
\end{tabular}


ii) Sagni Sweda:

\begin{tabular}{|l|l|l|l|}
\hline 1. & Sankara Sweda & 8. & Karshu Sweda \\
\hline 2. & Prastara Sweda & 9. & Kuti Sweda \\
\hline 3. & Nadi Sweda & 10. & Bhoo Sweda \\
\hline 4. & Parisheka Sweda & 11. & Kumbhika Sweda \\
\cline { 1 - 2 } 5. & Avagaaha Sweda & 12. & Koopa Sweda \\
\hline 6. & Jentaaka Sweda & 13. & Holaka Sweda \\
\hline 7. & Ashmaghana Sweda & & \\
\hline
\end{tabular}

\section{Classification of Swedana according to Acharya Sushruta:}

According to Acharya Charaka Sweda are four types; Tapa Sweda, Ushma Sweda, Upanaha Sweda and Drava Sweda.

\section{i) Tapa Sweda:}

It is a type of Agni Sweda involving direct contact of heat to the body.

\section{ii) Ushma Sweda:}

It produces fomentation in the body by the application of a piece of stone and brick etc. and sprinkle water. The fomentation must be made on the body which is covered with a cloth.

\section{iii) Upanaha Sweda:}

It is define as a hot poultice applied on the body and the bandage will be tied.

\section{iv) Drava Sweda:}

This involves direct contact of heat by any liquid to the body.

\section{Classification of Swedana according to its Guna:}

i) Snigdha Sweda (Unctuous or Wet fomentation):

It is define as that Sweda which is done with Snigdha or unctuous drug.

\section{ii) Rooksha Sweda (Rough or Coarse or Dry fomentation):}

This is being employed in the disorder of Kapha, Meda and Aamadosha etc. The materials used in Rooksha Sweda are sand, stone, metal and broken pot.

\section{Properties and Actions of Swedana drugs:}

The drugs to be used in Swedana or sudation therapy having Ushna (Hot), Teekshna (Sharp), Sara (Mooving), Snigdha (Unctuous), Rooksha (Rough), Drava (Liquid), Sthira (Immovable) and Guru (Heavy) properties.

\section{Sankara Sweda:}

Sankara Sweda refers to application of heat using the heated packs, which are prepared by medicinal leaves or boiled grains of sand tied on a piece of cloth packs. These warm packs are used for application of heat to the part of the body. Swedana can also be performed to the whole body. Patra
Pottali Pinda Sweda and Shashtika Shali Pinda Sweda is comes under the Sankara Sweda.

\section{Introduction of Patra Pottali Sweda:}

Application of the heat and there by inducing perspiration using heated pack of specific Vatahara herbal leaves like: Dhattura, Eranda, Arka and Nirgundi known as Patra Pottali Sweda. The word 'Patra' means 'leaves of medicinal plants' and 'Pinda' means a 'Bolus. Patra Pottali is derived from two words: Patra $=$ Leaves + Pottali $=$ Bundle. This Sweda is considered under the category of Snigdha Sweda and Ushma Sweda.

\section{Indication of Patra Pottali Sweda:}

The Indication of Patra Pottali Sweda is in Upstambhita Vata Vyadhi, Upastambhita Sandhivata, Katigraha (lumbago or low back ache), Manyastambha (cervical spondylosis), Stambha (tenderness) and Shotha (inflammation).

\section{Contra-indication for Patra Pottali Sweda:}

Any type of fomentation should not be prescribed for testicles, heart and eyes, if necessary mild type of fomentation should be prescribed. Moderate type of fomentation should be prescribed for the groins. Patra Pottali contra-indicated in the conditions where Swedana is not at all advisable.

\section{MATERIALS \& METHODS}

\section{Procedure of Patra Pottali Sweda:}

Patra Pottali Sweda involves Poorva Karma, Pradhana Karma and Paschaata Karma.

\section{Purva Karma:}

Eranda, Arka, Nirgundi, Dhatura, two pieces of clean cloth, thread, garlic, grated wet coconut, lemon, earthen pan, Vatahara Taila, towel, Droni and stove are required material. The herbal leaves are cut into small pieces and then taken in a vessel of round bottom, approximate $200 \mathrm{ml}$ of Vatahara Taila (viz. Nimba Taila or Tila Taila) is added to this with continuous stirring the leaves are then fried to make it plaint. This fried leaves is used for preparation of packs. 

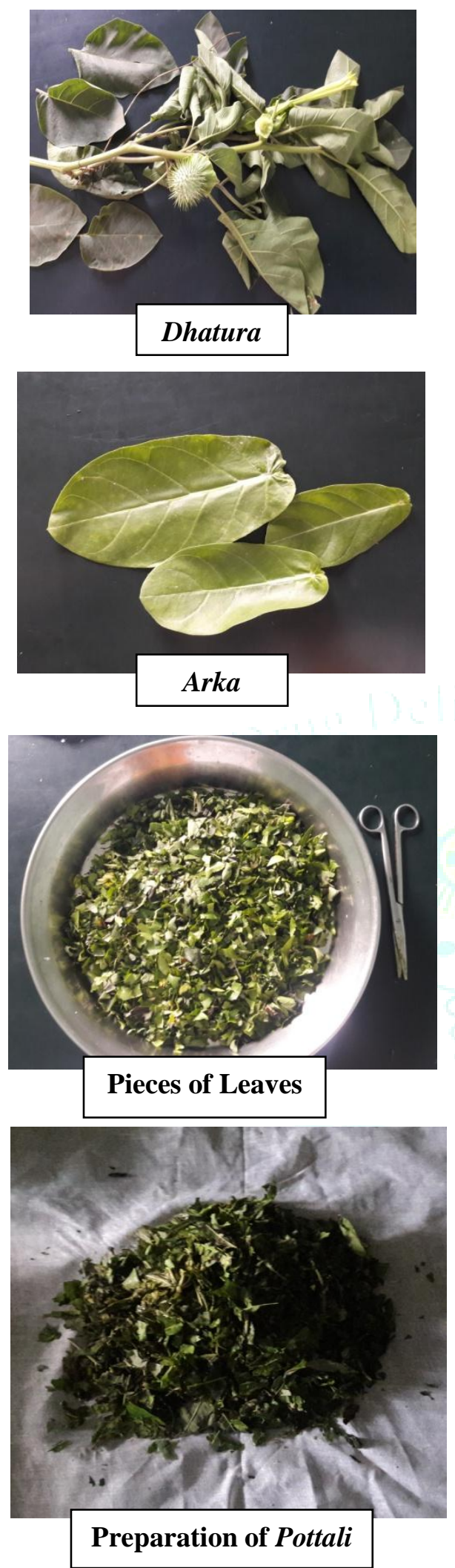

The patient should be seated with leg extended over the Droni facing to the east. Abhyanga should be performed with prescribed medicated Taila all over the body for about 10 minutes.

\section{Pradhana Karma:}

After the Abhyanga patient asked to sit on the Droni with extended legs, earthen pan is kept in mild flamed \& prescribed Vatahara Taila is poured $(10-15 \mathrm{ml}$. on each time
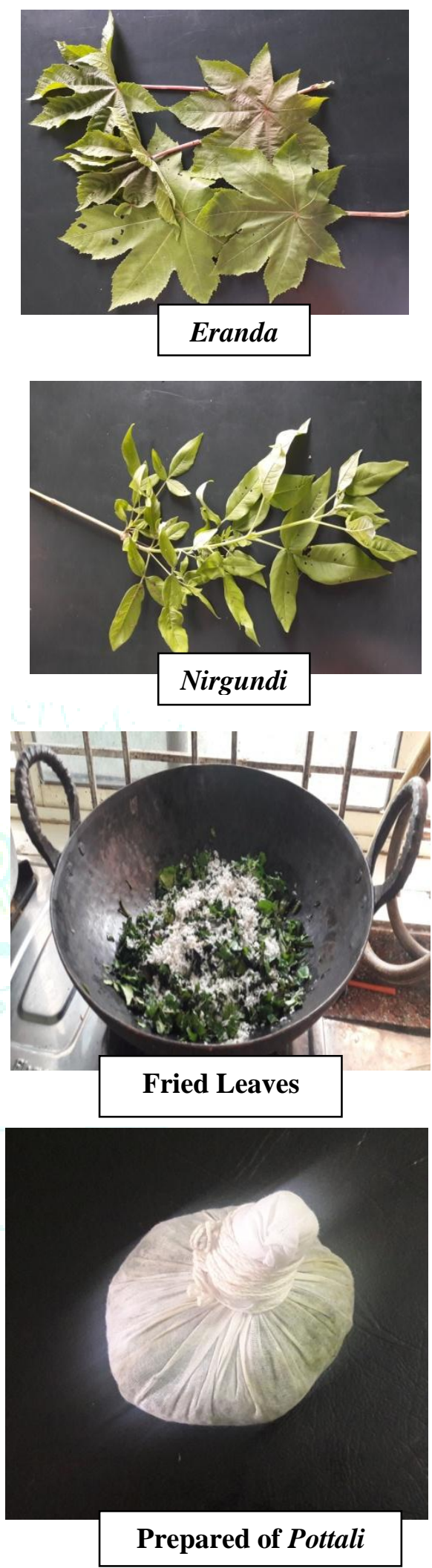

of dipping). Warm boluses are gently applied in a synchronized manner by two therapists positioned in each side of the patient. The therapists before applying the bolus on the body of the patient should ensure that the heat of the boluses is bearable to the patient by touching them to their own dorsum of the hand. Heat of the bolus should be maintained throughout the procedure by dipping it in the Vatahara Taila repeatedly. The process should be performed in all the seven positions advised by Abhyanga. The 
procedure of Patra Pottali Sweda should be done till the patient relieve from Samyak Swinna Lakshana. The leaves pack should be changed in every three days, duration of the procedure is according to the condition and requirement of the patient it should be continued for 7,14 or 21 Days.

\section{Precautions:}

Therapist should keep care while reheating Pottali and need to observe the temperature of the Pottali by place it over dorsum of hand. It is also need to check that temperature is bearable to patient or not.

\section{Paschata Karma:}

Wipe off the oil from the body using clean \& dry towel, body is covered with thin blanket for 10-15 minutes. Patient should be advised to take hot water bath after half an hour depending on diseases.

\section{Mode of Action:}

The Ushna Guna of Swedana Karma leads to stimulate the sympathetic nervous system \& produces vasodilatation. Ushna Guna also increases the circulation of Rasa \& Rakta in the body, due to effect of Sara \& Suksama guna of Swedana dravya the Leena Dosha are liquefied from body and came out through micropores presenting over the skin resulting more excretion of liquefied Vitated Dosa from body.

\section{Sign \& Symptoms of Proper Sudation (Samyaka Swedana Lakshana):}

After the Samyak Swedana coldness in the body should be observe along with relieve in stiffness. Reduction in heaviness of the body, softness \& appearance of sweating may be observed.

Sign \& symptoms of Improper Sudation (Asamyaka Swedana Lakshana):

Improper Asamyak Swedana may obstruct sweating, coldness not reduced, less sensation for cold things and no relief in pain.

\section{DISCUSSION}

Patra Pottali Sweda is used in Upstambhita Vatavyadhi. It is beneficial in conditions like Katigraha, Stambha, Manyastambha \& Shotha etc. Patra Pottali Sweda reduces pain \& stiffness. Patra Pottali is done when Vata and Kapha dosha are vitiated. Patra Pottali offers Sankara Swedana due to its Ushna Guna which ultimately stimulates sympathetic nervous system and enhances vasodilatation. The effect of Sara \& Sukshama Guna of Swedana Dravya liquefied Doshas which further excrete out through micropores presenting over the skin.4-6

\section{CONCLUSION}

In additions to this, in any patient if eliminatory procedure like Vamana or Virechana is planned, Swedana is performed as Poorva-karma and therefore is such situations Swedana is considered as Poorva-karma or preoperative procedure. Patra Pottali Sweda is one of the best Sankara Sweda prakara which is used to relief Stambha (stiffness), Shotha (inflammation) and Shula (pain). Patra Pottali Sweda works with the properties of anti-ageing and rejuvenation which also improve organic function, cell-tissue strength, blood circulation and promotion of vitality. Patra Pottali Sweda is type of Sankara Sweda which performed by herbal leaves and gives significant relief in Kaphavritta Vata Vikaras.

\section{REFERENCES}

1. Yadhavaji Trikamaji - Agnivesha Charaka Samhita - $5^{\text {th }}$ Edition Choukhambha Publication, Varanasi.

2. Gupta Kaviraj Atrideva - Ashtanga Hridaya Vidyotini Bhasha Commentory - Reprint Edition 2006 - Choukhambha Publication, Varanasi.

3. Pranita Kashirama - Sharangadhara Samhita Acharya Addhamalla Virachita Dipika Commentary - Krishnadesha Academy.

4. Dr. G. Shrinivasa Acharya - Panchkarma Illustrated Chaukhamba Sanskrit Academy - 2013.

5. Sharma Priyavritt - Chakradatta, Sanskrita text with English translation - $2^{\text {nd }}$ Edition 1998 - Publication, Varanasi.

6. Vaishya Kavivara Shaligramji - Vangasena with Hindi Tika 2003 Edition - Khemaraja Shrikrishnadas Prakashan, Bombay. 